\title{
THE BLUE FLAG PROGRAMME AS PRO-ENVIRONMENTAL BEHAVIOUR INSTRUMENT FOR COASTALDESTINATIONS: TOWARDS MUNICIPAL COASTAL GOVERNANCE ANDCOMMUNICATION
}

\author{
JĀNis Ulme ${ }^{1}$, Sintija Graudin̦a-Bombiza², Raimonds ERnSteins ${ }^{3}$ \\ Foundation for Environmental Education (FEE) Latvia (Latvia) / University of Latvia (Latvia)
}

\begin{abstract}
The research focuses on evaluation of the Blue Flag programme implementation in Latvia since the year 1998, when the programme's operations started. It includes analysis and an overview of both the national and local level impacts and the results of the programme implementation. With regard to national level, approach and experience, the overview focuses on effectiveness and the role of the Blue Flag programme as a supporting instrument for successful implementation of environmental legislation. This programme is also analysed as a communication instrument in promoting environmental policies within $500 \mathrm{~km}$ long of coastline areas, which in Latvia are announced the national interest territories aiming at both particular protection and also development, especially, as tourism destinations. On the municipal level, our approach and overview present analysis of the Blue Flag criteria and their implementation experience in different municipalities. Moreover, we study the overall impact of the programme on environmental performance of the municipal sector regarding coastal protection issues. The Blue Flag survey also reviews selected municipal case studies: Liepaja, Ventspils, and Saulkrasti. After reviewing the overall programme's performance in Latvia, the study concludes with an elaborated set of multi-level suggestions on potential improvements that would strengthen the programme's further implementation and facilitate better and wider use of its potential not only for particular designated and size limited coastal destinations as the Blue Flag beaches and marinas. The programme's potential could also be used for voluntary and facilitated coastal governance and coastal communication within the whole municipality and eventually further afield, turning from spreading of coastal information and almost established education towards coastal participation and the whole scale pro-environmental behaviour.

KEYWORDS: Blue Flag, coastal management, environmental communication, environmental policy.
\end{abstract}

JEL CODES: Q, Q5, Q56, Q58.

DOI:

Introduction. An asset for further developments

The Blue Flag is a voluntary programme, established and implemented by the international non-governmental organisation "Foundation for Environmental Education" (FEE International) as a tool to facilitate sustainable development in the coastal environmental management and water protection. During the program-

1 Janis Ulme - Foundation for Environmental Education (FEE) Latvia

Scientific interests: environmental and coastal policy

E-mail: janis.ulme@zemesdraugi.lv

Tel. +371225 52423

2 Sintija Graudina-Bombiza - University of Latvia, Department of Environmental Science

Scientific interests: environmental governance and public participation

E-mail: sintija.graudina@lu.lv

Tel. +37126827053

3 Raimonds Ernsteins - University of Latvia, Department of Environmental Science

Scientific interests: environmental and coastal governance, municipal planning and pro-environmental behaviour and communication

E-mail: raimonds.ernsteins@lu.lv

Tel. +37129476620 
me's history it has become a highly evaluated and recognisable eco-certification system, combining tourism and environmental aspects for common efforts for reduction of possible negative impact of the tourism and leisure sectors on the coastal environments. The Blue Flag is now widely recognized as, probably, the most popular tourism eco-certification system in the world. The programme has been working at the international level since 1985, with its expansion in Europe starting since 1987 and worldwide - since the year 2001.

Latvia began the implementation of the Blue Flag programme in 1998, when its participation in the scheme was prioritised by the Ministry of Environment seeking to motivate the performance of the municipal sector in the water and coastal management during the period of accession to the EU. Since then, the Blue Flag programme in Latvia has recorded steady growth and proven itself as a successful instrument, promoting the development of environmental governance and communication in municipalities, as well as obtaining the national importance as an instrument in achieving the targets of different aspects set out in the European environmental legislation.

In the Environmental policy guidelines 2014-2020, the Blue Flag programme is also mentioned as a positive example of the NGO (non-governmental organisation) and the municipal sector cooperation. that not only increases the capacity of the municipalities to solve local environmental issues, promotes sustainable tourism and environmentally friendly recreation, but also has an increasing role in environmental education and awareness raising of coastal users that visit the Blue Flag awarded sites. The Blue Flag programme provides significant contribution both in environmental education and public participation in environmental decision making. Therefore, the number of the certified Blue Flag bathing places has been chosen as an important performance indicator for the achievement of defined policy target „To ensure good water condition and its sustainable use" (National Environmental Policy Guidelines 2014-2020, 2014: 265).

The Blue Flag methodology currently incorporates 33 criteria in the four criteria groups or areas: water quality, environmental management, environmental education and information, and safety measures (Blue Flag Criteria and Explanatory Notes, 2017: 42). The important but sometimes neglected characteristic of the importance and impact of the Blue Flag methodology to coastal protection and development is that the implementation of the criteria set, at least in the main subprogram of certification - beaches, covers not only different aspects of the situation in the beach area, but covers municipality in a much broader sense.

Present studies of the Blue Flag programme focus on specific criteria, parameters and experience, but there is lack of broader analysis of the programme as an instrument to improve coastal governance and environmental communication at national and municipal level. Therefore, the aim of this study is to assess operational practice, wider potential and impact on environmental and sustainability governance for both all along coastal territories and other different pro-environmental development fields and areas in municipalities. The current study and publication have been prepared within the framework of the National research program SUSTINNO project "Environmental diversity and sustainable governance".

\section{Research-and-development frame methodology}

Within the research-and-development framework of the study, we went through the several Blue Flag program contexts that allowed us to analyse the programme implementation experience and practice in Latvia throughout its twenty years of operation. In each step of the programme development, there were also undertaken tasks seeking to elaborate recommendations for further policy improvements and actions towards more successful utilisation of the programme's potential. In the current part of our study we analyse information and data obtained from: the Blue Flag Latvia programme application surveys during the period 1998-2016, the Blue Flag Latvia programme quality control surveys (national/international level) of the period 1998-2016, the Blue Flag Latvia programme National jury decisions and coordination recommendation documents of the years 1998-2016, as well as data that were accumulated during the programme's initial impact assessment evaluation conducted in Latvia by FEE Latvia in 2015.

The basis of the research methodological framework was a review of relevant international publications, where we identified a number of the programme's potential limitations or risk factors. Then, by empirical 
research, we tried to identify these factors as present or absent within the national programme. Although a set of 33 criteria of the Blue Flag programme covers a wide range of factors, the methodology does not cover the totality of all possible environmental conditions, loads and risks, which would be applicable and cover typology of any beach and coastal zone (Nelson et al., 2000: 12). Similarly, the current balance among service and safety criteria versus other criteria, can increase environmental pressures in peri-urban or rural beaches that are not widely used as popular and densely used tourism destinations (Mir-Gual et al., 2015: 10). Additionally, the formal application of criteria can worsen the environmental situation (mechanized beach cleaning, infrastructure overcrowding, removal of algae and deer) (Mir-Gual et al., 2015: 10). It is also important to mention that many potential positive impacts of the environmental and communication criteria are dependent on the capacity of the municipal environmental institutions and their ability to implement communication measures effectively. The quality control of these criteria is not always very quantifiable and easy, and they are depending on the awareness level of the beach users (Lucrezi, Saayman, 2015: 11). Finally, the balanced implementation of the programme at municipal level is very linked to the overall administrative and operational capacity of the local institutions; taking into account the programme development, regional differences in the programme traditions and different motivations from the municipalities' side to engage into the programme, program basic aims and their implementation measures can differ from users' expectations and understanding about the programme (Marin et al., 2009: 10).

Firstly, we looked at the Blue Flag methodology as an environmental governance and communication instrument, looking at its evolution and development stages both in Latvia and at international level. This was essential as in practice it is possible to easily distinguish different development stages of the Blue Flag system both in Latvia and at international level - each new set of the five-year criteria period is putting forward new priorities and emphasis. Analysis shows that in public communication there are many misunderstandings and uncertainties about the Blue Flag programme content and services, but they are mostly linked to insufficient understanding of the programme and its actual targets and content.

Secondly, we went through the Blue Flag programme parameters focusing on the criteria and performing the analysis on the environmental governance and/or communication instruments' impact when applying the criteria set to municipal reality. The survey was conducted reviewing both aspects: opportunities that arise implementing the programme and risks or negative effects that have been worked on within in the previous research quoted at the respective chapters of our study. Concluding the risk-opportunities assessment part, based on a set of data available, we assessed the risks and opportunities balance in the programme's implementation practice in Latvia since 1998.

Thirdly, addressing the Blue Flag impact assessment in the implementation practice, we analysed the actual programme criteria implementation specifics in Latvia - determining its implementation scale (bathing area or the municipality in total), as well as existing experience and implementation practice, including identification of potential for improvements. In this part of the research, we based our work on available feedback from municipalities that have taken part in the Blue Flag programme in Latvia.

As for the fourth step, in the Blue Flag developments, we focused on case studies, reviewing experience, motivation and success of three different municipalities participating in the Blue Flag programme - Liepaja, Saulkrasti and Ventspils - which were also studied within the SUSTINNO project performing their coastal governance and monitoring research tasks. This document analysis and expert discussion have been complemented by in-depth semi structured interviews (15-25 in each case) with the main stakeholders that took place in Liepaja, Pavilosta, Ventspils and Dundaga municipalities, in summer of 2016. In this paper, the data was analysed mainly in relation to the Blue Flag instrument.

Then, in the next step, we were concerned about the Blue Flag being the one, though very successful, coastal destination (beaches, marinas) governance instrument, and the necessity to look for governance developments of the whole municipal-national coastline areas using the wide Blue Flag methodological practice. Subsequently, the first challenge was the size of a coastline to be covered by adequate (even selective) management, but there were also other and more complex challenges. The first dimension here was related to vertical management integration from a local case towards the municipality coastline and further to regional, 
national, and international management level. Actually, they were governance levels that need to be covered in the case following all governance process steps: problem analysis, policy formulation and its planning, implementation management and success monitoring. The next and integrated dimension was social-andecological interrelations at the coast, i.e., studies of the territory and its planning, what leads to horizontal integration too.

The existing local coastal management elements traditionally are not recognized as having influence on sustainable use of coastal resources. Therefore, no necessity to balance protection and development of resources as to sustainably use them in future development of the territory (Kerkhoff, 2005; Lagzdina et al., 2017 ) is observed. It is particularly important to facilitate understanding and governance of coastal socioecological system (SES) (Hopkins, Bailly, 2011; Karpouzoglou, 2016). Therefore, the governance dimension should be taken into account apart from integration of all triple bottom line sustainable development dimensions (Ernsteins, 2010; Cashmore et al., 2015; Kudrenickis et al., 2016).

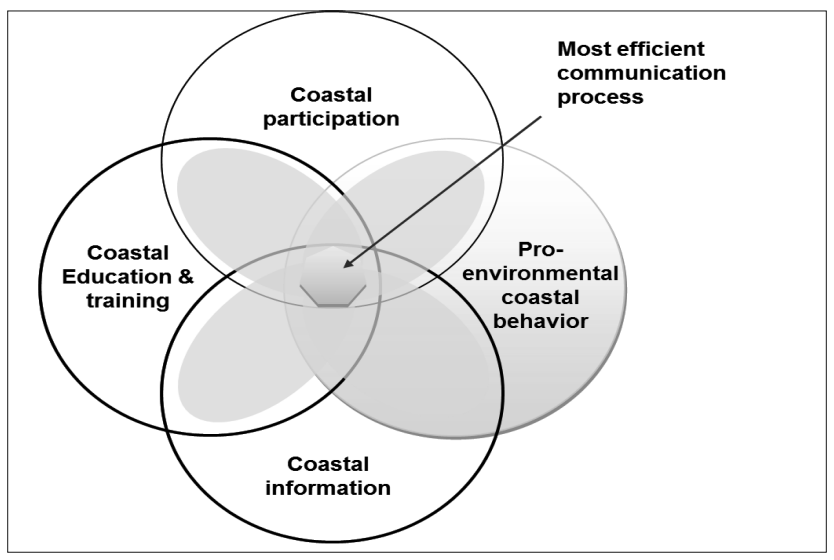

Fig. 1. Collaborative four instruments' communication model for ICM facilitation

Source: R. Ernsteins (2010).

Integrated coastal management (ICM) has been for a long known as a key principle in coastal governance development, but general international (Atkinson, Klausen, 2011) as well as Latvian ICM research results demonstrate that neither municipal leadership, nor other main stakeholders, including local inhabitants, are really aware of the complex and integrated nature of coastal governance processes and content, and the target groups participation (Ernsteins, 2010; 2017). Often lack of basic multi-thematical information and understanding becomes a limiting factor for ICM in everyday practice, what is not a dominating case with the Blue Flag territories and cases. Thus, information is becoming a necessary precondition for development and integration of coastal governance into the overall municipal development planning process: i.e., coastal communication which is widely understood from traditional coastal information, education/training instruments, coastal participation and pro-coastal behaviour; these issues are becoming the next key approach or even principle of ICM (Ernsteins, 2017) (see Figure 1).

\section{The Blue Flag experience and evolution context}

Nowadays, the Blue Flag brand is widely recognizable, though one of the programme's main challenges is that the brand is perceived very differently in different user groups and sometimes there are regional differences in understanding the brand, because for many beach users it still associates with water quality parameters only; in several regions of the world it firstly is associated with the high service quality on the beach and safe rest on water (safety measures and beach patrols); in separate user groups and regions it is recognised as environmental quality, environmental governance and the responsible environmental attitude 
quality mark. The understanding of the Blue Flag implementation specifics is very essential because in implementation practice the main risks for its credibility arise, when there is discrepancy between motivation or efforts of operators and understanding or perception of the brand by beach users or other target groups as local municipality inhabitants or the media. We have documented several examples in Latvia, when in practice there were periods when expectations of users did not line with the actual programme content, but they have not impacted programmes overall credibility.

Remarkable is the evolution of the Blue Flag approach. The basic rationale of Latvian government to consider and promote its involvement and support to the implementation of the Blue Flag programme at the end of the 1990s was a transposition of the EU environmental acquis - the EU Bathing Water Directive 76/160/EEC (later replaced by the 2006/7/EEC) and Urban Wastewater Treatment Directive 91/271/EEC. At that time, the Blue Flag programme had been already spread considerably within European countries and had proved its worth as a voluntary mechanism for environmental cross-sectoral cooperation. Additionally, positive potential impact of the programme activities on motivation and involvement of the municipal sector in the water management and coastal protection measures were identified at an early stage.

After Latvia had joined the European Union, the Blue Flag programme in Latvia switched the focus of its operation and encountered operative challenges, thus during the coming few years it put emphasis on the positioning the Blue Flag programme as an instrument that increases tourism destination attraction value. Developments nationally also mirrored parallel happenings at international level.

Since 2006-2008, the Blue Flag international criteria strengthened some environmental aspects and the programme in Latvia entered a new cycle of development - putting emphasis on the programme's value in environmental education, cross-sectoral cooperation and promotion of sustainable coastal management. As demonstrated in Figure 2 "The Blue Flag programme's growth dynamics in the Baltic States", at least at the beach operators' (municipalities) level such positioning ensured further and rapid development of the programme's activities in Latvia.

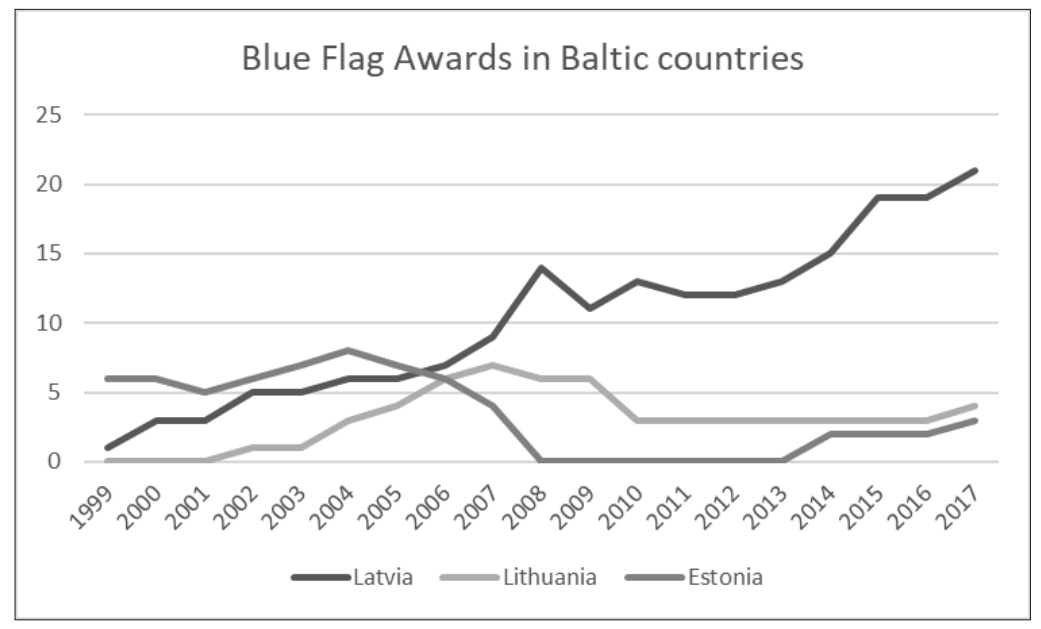

Fig. 2. The Blue Flag programme's growth dynamics in the Baltic States

\section{Wider impact of the Blue Flag programme on coastal governance and communication}

The chosen aim of our research was to look at the situation in Latvia with regard to environmental governance, specifically environmental communication and sustainable coastal management and development. The Blue Flag programme within its 20 years' experience in Latvia has become a flagship for both of our priority themes. Therefore, we decided to focus on it, identifying the existing experience of the Blue Flag programme's implementation and in-depth analysis of its strengths, weaknesses and potential. 
Assessing the Blue Flag programme's impact on the environmental policy and legislation implementation, coastal governance and environmental communication, it is essential to take into account, that the Blue Flag criteria are multilayered by their operational scale. Although the Blue Flag certification refers to the designated bathing area, respectively to an officially recognized beach, criteria by their operation are divided into ones which refer only to the beach situation, and the ones that refer or have impact on the municipality in general.

We selected a batch of criteria groups that were identified as the most important for governance and communication aspects of the programme and looked at their implementation experience in Latvia, assessing their operational scale as well as their implementation success and challenges. The sources used in this study are represented in Table 1: the Blue Flag International control visits report forms of Latvia 2016; the Blue Flag International database 2017; the Blue Flag Latvia application questionnaires of 1998-2017; Quality control reports of the programme implementation in awarded sites during the season of 1998-2017; Recommendation and application decision documents of the Blue Flag National Jury and National Operator 1998-2017.

Table 1. Area, scope and impact of the selected Blue Flag criteria on environmental communication and coastal management

\begin{tabular}{|c|c|c|c|}
\hline $\mathrm{Nr}$ & Criterion conditions & Area & Scope \\
\hline 1 & Blue Flag information & Communication & Beach \\
\hline \multicolumn{4}{|c|}{$\begin{array}{l}\text { The criterion includes a number of parameters that need to be implemented in the Blue Flag awarded site during } \\
\text { the bathing season with regard to the communication with beach users - both in content and format. It must be } \\
\text { recognised that despite it being a technical criterion, municipalities often face challenges in proper implementation. } \\
\text { Based on accumulated information of the programme experience in Latvia, we concluded that the main reason for } \\
\text { the implementation gaps is the fact that municipalities often see the so-called "soft" communication criteria as the } \\
\text { formal ones and do not put high priority on their implementation, even though they can hugely benefit and improve } \\
\text { environmental communication with direct target groups of beach users. } \\
\text { Over the years, a number of steps for improvement of the implementation rate has been already taken both by the Blue } \\
\text { Flag coordination and municipalities themselves: standardised beach posters, training, etc. } \\
\text { The criterion is linked with the other following criteria of the Blue Flag programmes: }\end{array}$} \\
\hline
\end{tabular}

Taken as a set of interlinked communication parameters, these criteria ensure the sufficient and proactive communication with both direct beach users and coastal users in a broader sense of a term.

By increasing municipalities' awareness about efficient information service to different audience, they also serve as educational and best practice tools, multiplying their impact on other aspects of the municipal environmental, in particularly environmental governance aspects.

\begin{tabular}{l|l|l|l}
2 & Environmental education activities & Communication & Municipality
\end{tabular}

Each municipality taking part in the Blue Flag scheme must provide at least 5 environmental education activities for beach users and general public throughout the season and the calendar year of certification.

This criterion has proven itself as one of the largest importance and impact. The Blue Flag programme in Latvia have also developed stringent qualification criteria for environmental education activities to be included in annual applications, therefore the activities have become more focused over the years, minimizing the risks of formal implementation. Also, the municipalities during the planning and implementation of this criterion must consider municipal environmental communication in general, not only for beach users throughout the bathing season.

Thus, the amount of environmental education activities that are implemented annually within the Blue Flag programme ranges between 60 and 80 initiatives. Activities include a broad range of methods and target audience - starting from beach events to environmental cooperation platforms with NGO's, cooperation activities for schools, direct events, contests, media broadcasts, etc. As the Blue Flag events must be separated and distinct from day-to-day municipal activities, local communities also benefit from this criterion by bringing additional support resources (including financial support) to local environmental initiatives. 


\section{2 Beach management committee \\ Management/Communication $\quad$ Municipality}

The criterion determines that working with questions related to bathing areas and coastal management, it is necessary to set-up a municipal level coordination group. This is one of the new Blue Flag criteria that appeared in the programme in the latest criteria set cycles and has been introduced quite recently. The criterion also determines that operation of the committee must be open for public participation and must oversee the programme's integration with nearby nature protection territories and their respective bodies/authorities. According to the assessed documentation about the recent implementation experience (applications, coordination recommendations, control results), implementation of the criterion does not go equally successful in all municipalities, however in those, where it is introduced according to the substance, it has brought clearly positive contribution to the management quality improvement and interinstitutional cooperation promotion, being seen as the key issue, required for integrated coastal governance development.

\begin{tabular}{l|l|l|l}
14 & Management of nature sensitive territories & Management/Communication & Municipality
\end{tabular}

For beaches with the necessity of special management regime, based on nature protection considerations, the municipality must invest additional conservation efforts involving relevant experts and organisations. In accordance with the assessed documentation about implementation experience (applications, coordination recommendations, control results), and taking into account that in Latvia there have been no precedents where, due to nature protection considerations, the Blue Flag bathing areas should apply drastic restrictions for visitors' flow, introduction of this criterion has not caused problems. In places, where near bathing areas are located nature protection territories, this criterion has promoted interinstitutional cooperation.

\begin{tabular}{|l|l|l|l|}
15 & Beach cleanliness & Management & Municipality (LAT)
\end{tabular}

The criterion determines that the Blue Flag beaches must be clean, and it gives methodological advice for validation of that status. In Latvia, the criterion is linked with broader urgency of marine litter issues. It has promoted the Blue Flag campaigns leadership in marine litter issues, as well as in tackling of environmental issues both at local and national level. Taking into account that this is one of the new generation Blue Flag criteria, though perfection of its methodological basis is still in process, the created system in Latvia provides broader alternative for the basic criteria methodology or so-called A+ assessment system on the 10x10 meters assessment areas. It is realised by linking the Blue Flag status to the actions regarding marine litter throughout the whole stretch of the municipal coastline (for beaches located in Riga bay of the Baltic Sea open waters).

It ensured involvement and practical activities of the Blue Flag municipalities in the emerging marine litter policies, as well as widespread attention to this issue at national level. Similar to the water quality and environmental activities criteria, this in perspective will become a qualification criterion claiming for the Blue Flag certification.

\begin{tabular}{l|l|l|l}
\hline 17 & Waste collection/management & Management & Beach
\end{tabular}

The criterion determines demands for waste containers location on and nearby the beach, as well as helps to elaborate on the methodology defining planning and management of their density. According to the assessed documentation about implementation experience (applications, coordination recommendations, control results), introduction of this criterion sometimes has been challenging for bathing area managers but achieved much greater attention on waste management in coastal areas. Also, the waste related criteria in the Blue Flag programme have achieved increased attention related to importance of recyclable waste facilities. Necessary improvements for the criterion implementation are possible to achieve by raising managers awareness about linkages between waste management practices and planning mechanisms applied for the site use in peak hours or months. Significant improvements can be reached also by linking management criteria with communication aspects of the programme.

\begin{tabular}{l|l|l|l}
22 & Unauthorized activities on the beach & Management & Municipality
\end{tabular}

The criterion determines restrictions for some actions on the beach and neighbouring areas and specifies visitors' information about these restrictions. According to the assessed documents related to implementation experience (applications, coordination recommendations, control results), no significant problems there have been observed in its implementation. The criterion in practice is applied to the whole municipality, because restrictions for some actions, as well as creation of controlling mechanisms, have also encouraged identical behaviour in other managed coastal zones. It must be taken into account that in many cases restrictions are determined also by the national legislation.

\begin{tabular}{l|l|l|l}
\hline 26 & Promotion of sustainable transportation & Management & Municipality
\end{tabular}

This criterion provides the necessity to promote sustainable modes of transportation (public transport, cycling transport) to and from the beach. In accordance with the reviewed documentation about implementation experience (applications, coordination recommendations, control results), no shortcomings have been observed. It has promoted wider use of public transport, as well as benefited cycling and pedestrian mobility solutions. 


\begin{tabular}{|c|c|c|c|}
\hline 29 & is & Ma & \\
\hline \multicolumn{4}{|c|}{$\begin{array}{l}\text { The criterion regulates the necessity of municipal level emergency plans to be in place and determines that emergency } \\
\text { actions within it include actions on the beach and coastal areas. The criterion is important for its emphasis on coastal } \\
\text { areas that must be taken into account assessing the risks and emergency plans. Implementation status of this criterion } \\
\text { in Latvia is satisfactory and it has worked as a tool for strengthening and broadening the municipal, regional or site- } \\
\text { specific emergency measures to be included in plans. }\end{array}$} \\
\hline 30 & $\begin{array}{l}\text { Beach zoning and different user groups } \\
\text { management }\end{array}$ & Management & Beach \\
\hline \multicolumn{4}{|c|}{$\begin{array}{l}\text { The criterion sets out the methodology for avoiding conflicts and risks arising from different interests of beach users. } \\
\text { According to the documentation reviewed during research, it is implemented in a satisfactory way, however still } \\
\text { needs adjustments and improvements. Similarly to many communication criteria, sometimes the implementation } \\
\text { of it is treated as a formality. Nevertheless, the criterion succeeded in raising awareness of municipalities about } \\
\text { the different beach user groups and their needs, so that the lessons from the Blue Flag implementation were further } \\
\text { taken into account in broader coastal management initiatives and beach management. For example, by setting up and } \\
\text { clarifying management routines in surfing areas or nudist beaches within the municipal stretches of the coastline. }\end{array}$} \\
\hline
\end{tabular}

\section{The Blue Flag local case studies and municipal profiles}

Assessing the Blue Flag implementation experience and practice, we also focused on motivation, success and lessons of different municipalities that took part in the Blue Flag programme. Within the framework of the research, we have chosen the following coastal municipalities: Liepaja, Ventspils and Saulkrasti. These municipalities reflect the diversity of the programme.

Liepaja. In the Blue Flag programme, Liepaja got involved already in 1997 as one of the first municipalities. Currently, there are four certified sites in the municipality: two coastal beaches, an inland beach and marina. The municipality had the following reasons to start up the programme implementation: certification as an acknowledgement of high environmental standards and performance in the municipality; the Blue Flag contribution to the promotion of the destination and tourism; as well as the Blue Flag methodologies' input in organization of coastal management and governance. Reviewing implementation and the history of the programme, the main challenges for the municipality were: bathing water quality compliance (two beaches), infrastructure eligibility (building and sanitary) criteria, waste management quality, as well as in several sections, at the horizontal level, general capacity to work successfully with the programme administration. According to the self-evaluation of the benefits from the programme, done by the municipality within the framework of initial impact assessment carried out by FEE Latvia in 2015, it has been acknowledged that the municipality has benefited from participation in the programme quite diversely: the municipal capacity in managing the environmental governance of coastal and bathing areas has increased; the programme also gave impulses for strengthened environmental communication and public involvement and opened new possibilities and positive profiling of Liepaja city as a tourism destination. Participation in the programme also brought opportunities to attract additional financial resources, including EU structural fund financing for the necessary infrastructure improvements and management and capacity building of safety personnel.

Ventspils. Ventspils involved in the Blue Flag programme in 1997 and was the first municipality in Latvia and the Baltic States to receive certification status already in 1998, since then receiving the Blue Flag already each consecutive season up to date. Currently, there is one Blue Flag certified site in Ventspils municipality - Ventspils City beach. The main rationale behind the municipality involvement in the programme was a serious strategic vision about the municipality's positioning and profiling in the context of environmental protection, as well as interest in coastal (beach) management methodology. Reviewing the programme's implementation experience at municipal level, it must be noted that during the entire history of participation in the programme, there have been recorded no violations or challenges, as it has always been activity of high priority for the municipality. According to the self-evaluation of benefits, done by the municipality within the framework of initial impact assessment of the programme carried out by FEE Latvia in 2015, it has been acknowledged that participation in the programme has brought the expected positive 
results in positioning and destination promotion activities. It is also an example of good level implementation in many other aspects, namely, the use of the programme's criteria potential in methodological coordination of environmental communication and coastal management.

Saulkrasti. Saulkrasti joined the Blue Flag programme in 2014. The main motivation of the municipality to engage in the programme was destination promotion and positioning. Also, the Blue Flag certification was considered as a quality label that emphasises considerable work done by the municipality in the water management sector.

Assessing the programme implementation experience and practice in the municipality, it must be admitted that the municipality faces a series of problems in maintaining the implementation quality (similarly as several other small municipalities in Latvia), starting from management quality during the season up to the communication criteria implementation gaps. To a large extent, these problems relate to one issue - initial capacity of municipality institutions to implement the programme. Nevertheless, despite several implementation challenges within the first years spent in the programme, participation in it has brought the expected results, allowed to attract additional resources for further improvements and have served as motivation for capacity building in coastal management within the municipality.

\section{Discussion on the Blue Flag programme implementation in Latvia: benefits, limitations, risks and potential improvements}

Summarising the Blue Flag implementation experience in Latvia based on the reviewed information and gathered data as well as feedback about the programme implementation, we conclude that the programme has brought diverse benefits to participating actors. At national level, the programme's contribution to the promotion of environmental and public health legislation and policy introduction is most often mentioned as the most significant implementation benefits. Moreover, the programme's efforts promoting cooperation in environmental protection, the Blue Flag potential and contribution to environmental communication and actualization of environmental questions are also widely recognised. At municipal level, local level operators indicated the Blue Flag as a system that provides methodology and practical knowledge of coastal sustainable management principles thus strengthening Latvian tourism positioning. Furthermore, this programme has been acknowledged as practically applicable methodology, which covering all sectors involved in beach management and based on the wider coastal governance context, allows to minimise the negative potential impact of the tourism sector matching coastal developments with environmental interests. Over the years, municipalities have widely used the programme given possibilities to attract financial resources for improvement of the coastal management situation and infrastructure projects. All municipalities evaluated the Blue Flag as an environmental quality status label, stressing both its importance in tourism promotion, and also as accreditation which is also important for municipal inhabitants themselves.

Within the framework of implementation evaluation, we also focused on the identification and research of the possible programme's limitations and nominal risk factors. In the assessment of Latvia's performance within the programme, at least from the side of the programme partners and local operators, not many risk factors have been found. We also identified a broad range of possible improvements for the programme implementation at different levels:

1) National level (institutional and regulatory framework)

- Better integration and linkage of the programme to national regulations. Despite that the Blue Flag is widely used as a voluntary environmental policy promotion tool (being integrated into Environmental Action Plan and the sectoral target), there is potential for more thorough and integrated improvements that would allow to fully use the programme's potential.

- Better sectoral integration (tourism, public health, municipal coastal management). Currently, participation of other stakeholders than the Ministry of Environment, namely, the Ministry of Health (the competent authority on quality of bathing water), the Ministry of Economics (the competent authority on tourism), the Union of Municipalities, etc., are limited to participation in the National Jury and 
quality control procedures. Broader integration with the sectors can increase the programme's input in the sectoral initiatives, multiplying its value.

- Strengthening of the national quality award system for beaches. The National Award (Beach Quality Certificate) is developed and run in Latvia by FEE Latvia in cooperation with the Ministry of Environmental Protection and Regional Development as a qualification and support tool for municipalities that begin the road to the Blue Flag certification. Further strengthening of the scheme is important for growth of the programme, dissemination of its methodology and promotion of better implementation of environmental policies at municipal level.

- Capacity building of the programme. In the past years, the programme support was fragmented and limited, nevertheless, it is currently renewed at the level of 2008, covers just slightly more than half of its costs, thus limiting possibilities for additional activities, or strengthening of implementation and activities of underestimated value, as training and information services to municipalities.

2) National level (communication and quality control)

- Targeted campaigns and activities focusing on certain priority areas important for environmental policy at national level and implemented through strengthening of criteria and quality control procedures. Utilisation of the programme potential (as proven by undertaken proactive activities in areas like marine litter and beach risk assessments) can seriously improve municipal level performance.

- Broadening of the programme positioning and sectoral impact on policy improvements. The Blue Flag is currently widely recognised as an environmental quality award in Latvia. Within recent years, thanks to national initiatives, the programme has developed into the driving force behind other environmental initiatives as marine litter awareness raising. There is potential to use this experience to tackle other environmental and coastal management challenges (such as local public participation facilitation, safety on beaches, etc.), where the programme's impact is limited due to capacities and resources.

- Further research on target priority audience, such as beach operators and beach users, seeking to identify the reception and expectations of the programme, followed by communication activities based on research. It is of utmost importance because it is one of the main tools to manage the identified risks referred in this survey. Based on further research and work with target groups, it is possible to set up actions to mitigate the identified risks.

3) Municipal level

- Increased cooperation among the Blue Flag municipalities in Latvia. The programme in Latvia includes a diverse range of coastal situations and beach typologies among the awarded sites: from inland beaches to coastal beaches, privately and publicly managed, large city beaches with dense tourism load to rural beaches. Within those municipalities, there is a valuable experience and numerous best practice examples in the programme implementation. By strengthening cooperation among Latvian municipalities, potential of the programme can be utilised more efficiently.

- Usage of the Blue Flag brand for development of additional initiatives in sustainable coastal management and environmental communication areas. According to the initial assessment of the programme's impact, a number of the Blue Flag municipalities already use their experience gained within the programme implementation. It helps them to elaborate and implement projects linked to certain areas of the Blue Flag set criteria, i.e., beach infrastructure improvements, aspects of beach safety, environmental activities, etc. By coordinated facilitation of such initiatives, the programme would gain considerable additional resources at local level, enhancing attractiveness of certification for other municipalities in Latvia.

- Involvement of the programme's local institutions, in particular, the beach management committee. Developments in the Blue Flag criteria open a possibility to engage the beach management committee in setting a broader agenda for coastal protection and sustainable management promotion as it actually includes all the main stakeholders. 
- Integrated implementation of the public participation, information and environmental education criteria. The group of environmental education and information criteria is still among the ones which implementation gaps are identified most often both at national and international level. Therefore, additional efforts must be made to increase understanding of these criteria and in turn implementation improvements must be facilitated by giving more specific and focused explanatory guidance.

4) National Operator level

- Strengthening the training programme for the Blue Flag stakeholders at national and municipal level. To better use potential of the programme in promoting sustainable coastal management, the existing training programme must be adapted so that it would include these aspects. Also, the audience for training must be widened including more representative audience apart from local beach operators and the municipal Blue Flag coordinators.

- While tracking the performance improvements, there should be improved: clarification of information, education and communication aspects of criteria, elaboration of quantitative evaluation tools. There have been noticed considerable improvements in implementation of these criteria, but still, several implementation gaps and challenges referring to the quality control of environmental education activities are observed. Choosing more precise and, if possible, quantifiable methodologies that are openly and transparently communicated to the Blue Flag applicants will enable to tackle those deficiencies much more efficiently.

- Use of national extra-criteria mechanisms and national initiatives to promote environmental policy priorities.

\section{Conclusions}

Evaluation of the programme's benefits and limitations, including a review of the risks, allowed us to conclude that generally the Blue Flag programme implementation in Latvia has brought benefits and serves as an important governance instrument for both the coastal destinations' sustainable management and the municipal environmental governance. The programme has improved environmental information and further on step-wise towards the four instruments' complementary communication about a number of problem questions on coastal and environmental quality, thus promoting cooperation while introducing the environmental protection legislation and policy.

The separate identified program restrictions in Latvia do not cause threats to the programme's integrity, as only a few of restrictions and the reviewed risk factors are applicable to the programme's national implementation experience. However, those risks must not be neglected in further development of the programme activities and should be dealt on a regular basis through regular communications between the operator and municipalities, involving also the national Blue Flag Supervising council (jury) at national level and the local Blue Flag coordination groups; these groups should be formally and legally established in municipalities as an important tool, and their number should be growing.

It is also our conclusion that there is still a possibility to maximise the step-wise utilisation of potential of the Blue Flag programme as a sustainable coastal management tool for the whole municipal sector and the whole national coastline. Our proposed priority actions for the programme improvements at national level are stated in Chapter 5. Based on our knowledge about the programme implementation in other countries, we assume that in some cases these points can be also multiplicated by other countries and regions.

\section{Acknowledgements}

The conducted study and the paper were prepared at the University of Latvia, the Department of Environmental Science, within the framework and with financial support of the National research programme SUSTINNO project "Environmental Diversity and Sustainable Governance" as well as in collaboration partnership with the Blue Flag programme Latvia. The study has been based on further piloting municipal pro- 
environmental development research and partners who contributed to the project should be acknowledged, namely: Anita Lontone, Ingvars Lerhs, Ilga Zilniece, Uǵis Rusmanis, Krista Osniece, Ivars Kudrenickis, Janis Kaulins, Andris Kepals.

\section{References}

Atkinson, R., Klausen, J. E. (2011). Understanding Sustainability Policy: Governance, Knowledge and the Search for Integration. Journal of Environmental Policy \& Planning, Vol. 13(3), p. 231-251.

Blue Flag Criteria and Explanatory Notes. (2017). FEE International, Denmark.

Blue Flag International Control Visits Report Forms Latvia. (2016). FEE International, Denmark. Internal document. Blue Flag International Database. (2017). FEE International, Denmark. Internal database.

Blue Flag Latvia Application Questionnaires. (1998-2017). FEE Latvia, Riga. Internal documents.

Cashmore, M., Richardson, T., Rozema, J., Lyhne, I. (2015). Environmental Governance through Guidance: The 'Making up' of Expert Practitioners. Geoforum, Vol. 62, p. 84-95.

Ernsteins, R. (2010). Sustainable Coastal Development and Management: Collaboration Communication and Governance. Human Resources - the Main Factor of Regional Development. Journal of Social Sciences, No. 3, p. 247-252. Klaipeda: Klaipeda University.

Ernsteins, R., Lontone-Ievina, A., Lagzdina, E., Osniece, K., Kaulins, J. (2017). Integrated Coastal Management Practice Case Studies: Deficiency of Collaboration Communication and Socio-Ecological System Approaches. Proceedings of the International Scientific Conference "Economic Science for Rural Development", Vol. 45, p. 63-70. Jelgava: LLU ESAF.

Hopkins, T., Bailly, D. (2011). A Systems Approach Framework for Coastal Zones. Ecology and Society, Vol. 16(4), p. 25.

Karpouzoglou, T., Dewulf, A., Clark, J. (2016). Advancing Adaptive Governance of Social-Ecological Systems Through Theoretical Multiplicity. Environmental Science \& Policy, Vol. 57, p. 1-9.

Kudrenickis, I., Ernsteins, R., Kaulins, J. (2016). Sustainable Coastal Science-Policy-Practice Interface Development: Municipal Coastal Governance Indicator System. International Journal of Environmental Science, Vol. 1, p. 255-264.

Lagzdina, E., Kudrenickis, I., Ernšteins, R., Lontone, A. (2017). Municipal Coastal Governance Towards Rural Community Resilience Development: Scenarios and Tools. Sustainable Development and Planning. WIT Transactions on Ecology and the Environment, Vol. 226, p. 297-309.

Lucrezi, S., Saayman, M. (2015). Beachgoers' Demands vs. Blue Flag Aims in South Africa. Journal of Coastal Research, Vol. 31, Issue 6.

Marin, V., Palmisani, F., Ivaldi, R., Dursi, R., Fabiano, M. (2009). Users' Perception Analysis for Sustainable Beach Management in Italy. Ocean \& Coastal Management, Vol. 52, Issue 5.

Mir-Gual, M., Pons, G. X., Martín-Prieto, J. A., Rodríguez-Perea, A. (2015). A Critical View of the Blue Flag Beaches in Spain Using Environmental Variables. Ocean \& Coastal Management, Vol. 105.

National Environmental Policy Guidelines 2014-2020 / Vides politikas pamatnostādnes 2014.-2020.gadam. (2014). Ministry of Environmental protection and regional development / Vides aizsardzības un reǵionālās atț̄istības minitrija, Rīga, Latvia.

Nelson, C., Morgan, R., Williams, A. T., Wood, J. (2000). Beach Awards and Management. Ocean Coast. Management, Vol. 43, Issue 1.

Quality Control Reports of the Programme Implementation in Awarded Sites during the Season. (1998-2017). FEE Latvia, Riga. Internal documents.

Recommendation and Application Decision Documents of the Blue Flag National Jury and National Operator. (19982017). FEE Latvia, Riga. Internal documents.

Van Kerkhoff, L. (2005). Integrated Research: Concepts of Connection in Environmental Science and Policy. Environmental Science \& Policy, Vol. 8, p. 452-463. 


\title{
A PLINKOSA UGOS PAKRANČIŲ INSTRUMENTO PROJEKTAVIMAS - ,MELYNOSIOS VÉLIAVOS “ PROGRAMA. SAVIVLDYBËS PAKRANČIŲ VALDYMAS I R KOMUNIKA C I J A
}

\author{
JĀnis Ulme, SintiJa Graudiña-Bombiza, Raimonds ERnsteins
}

Aplinkosaugos fondas (AF), Latvijos universitetas (Latvija)

\section{Santrauka}

Moksliniai tyrimai šiame straipsnyje orientuoti i „Mèlynosios vèliavos“ programos igyvendinimo vertinimą Latvijoje. Programos, kuri pradèta vykdyti 1998 metais, vertinimas būtinas. Atliktas tyrimas apima nacionalinio ir vietos lygio poveikio bei programos įgyvendinimo rezultatų analizę ir apžvalgą. Kalbant apie nacionalinį lygmenį, pateikti požiūriai ir igytos patirties, susijusios su „Mèlynosios vèliavos“ programos veiksmingumu ir vaidmeniu, apžvalga, padėsianti sėkmingai įgyvendinti aplinkosaugos teisès aktus. Taip pat kaip komunikacinè priemonė propaguoti aplinkosaugos politiką maždaug $500 \mathrm{~km}$ ilgio pakrantès zonose, kuri Latvijoje paskelbta kaip nacionalinès svarbos teritorija. Šioje teritorijoje siekiama ir ypatingos apsaugos, ir plètros, ypač galimose turizmo vietose.

Savivaldybės lygmeniu rezultatai atskleidžia ịvairių savivaldybių „Mėlynosios vėliavos“ kriterijų taikymo patirtị ir programų poveikị bendruomenei pakrančių apsaugos klausimais. Atliktos apklausos dèl „Mèlynosios vèliavos“ programos veiksmingumo ir atvejų tyrimai atrinktose savivaldybėse - Liepojoje, Ventspilyje ir Saulkrastuose. Išnagrinejjus programos veiklos Latvijoje rezultatus, tyrimai baigiami parengtais pasiūlymais, kurie paskatintu programos veiksmingumą. Rekomendacijos padètu geriau išnaudoti esamą potencialą ne tik „Mèlynosios vèliavos“ paplūdimiuose ir prieplaukose, bet ir savivaldybių lygmeniu, siekiant jų komunikacijos veiksmingumo. Pagaliau tai naudinga ne tik konkrečioms savivaldybėms, kur yra pakrančių, bet ir visai šaliai, nes ugdomas aplinkosauginis požiūris, šviečiami ir ugdomi piliečiai.

PAGRINDINIAI ŽODŽIAI: mélynoji véliava, pakrančiu valdymas, komunikacija, aplinkosaugos politika.

JEL KLASIFIKACIJA: Q, Q5, Q56, Q58

Received; 2017.12.28

Reviesed: 2018.01 .10

Accepted: 2018.02.01 